\title{
Research on the Innovation and Development of Ideological and Political Education in Universities
}

\author{
Zhu Chenglei \\ Zhongnan University of Economics and Law, Hubei, China, 430073
}

Keywords: Pluralism; values; college ideological and political education

Abstract: With the continuous advancement of computer technology, network technology has penetrated into every corner of life. People's life production methods have changed greatly with the use of computers. Various cultural ideas are flooding the network. In particular, the values of Western countries have a great impact on the thinking of young people in China. The values of college students are gradually diversified, which brings many challenges to the ideological and political education in colleges and universities. The traditional ideological and political education in colleges and universities is no longer used by college students. Need to find a more appropriate education method.

\section{Introduction}

The ideological and political education work is referred to as ideological and political education. It is an educational activity adopted to achieve certain political goals. By transforming people's thoughts and guiding actions, the fundamental purpose of ideological and political education work is not to improve individual political concepts, but to Scientific theory forces itself to bring convenience to later life. College students' ideological and political education is concerned with socialist construction. The education of values has always been one of the main contents of ideological and political education in colleges and universities. The values of life are the concentrated expression of social values. The main task of ideological and political education in colleges and universities is to stimulate the sense of responsibility of college students and establish correctness. Values, contribute to the building of civilization[1].

\section{The relationship and influence of values and ideological and political education}

Philosophically, values are a specific relationship between people and things. Values are diverse in themselves. They have different values in different historical periods. They reflect social consciousness. Values represent people's evaluation of things and their lives. Both have a guiding role. Since China's reform and opening up, with the continuous development of economic globalization, values have gradually diversified, and the reasons for the formation of pluralistic values are mainly due to the following points: the social hierarchy and cultural background of the first people are different. There is a big difference in thinking. Second, the advent of the Internet era, a large amount of information has entered the network, affecting people's judgment standards. At present, the values of pluralism are mainly reflected in two aspects. The correct values refer to 
noble characters and pursuits, and the wrong values are the ideological concepts that socialist construction runs counter to. Diversified values have contributed greatly to the advancement of society, but society has also brought a lot of trouble[2].

Since the founding of New China, there have been many changes in values. In the primary stage of socialism, the task center of the state was to consolidate the people's political power, and everything was to stabilize the socialist system. Therefore, the value orientation of college students at that time was to achieve communist struggle for a lifetime. Personal interests obey the collective interests, completely discarding individual pursuits, and greatly promoted China's socialist construction. In this period, the main point of ideological and political education in China's colleges and universities is to transform the ideological and political education of college students with Marxist political theory. Since the Third Plenary Session of the Eleventh Central Committee of the Communist Party of China, the Party's program has established a concept of emancipating the mind. China has gradually entered the stage of reform. At the beginning, it was a period of exchange and friction between old and new institutions. At this stage, the concept of college students has changed and has been shaken off[3]. The original blind and personal worship thoughts gradually changed into a selection stage, and the values of self-consciousness gradually awakened. At the stage before 2000 , the values of college students have been integrated between social values and human values. The main task of ideological and political education in colleges and universities is to guide college students to connect and form values, and to eliminate conflicts between self-values and social values. Since the beginning of the 21 st century, the domestic situation has undergone a great transformation. With the continuous development of economic globalization, multiple values have gradually formed, and the values of college students have diversified. At this stage, the ideological and political education in colleges and universities needs to be people-oriented and more suitable. The way to guide the thinking of college students.

\section{Current situation of ideological and political education under the multi-values of current college students}

Under the diversified status of college students' values, it poses great challenges for the ideological and political education in colleges and universities. At present, the ideological and political education in colleges and universities mainly includes the following aspects. With the advent of the era of networking, the ideological concepts of college students have gradually become blurred, and confusion has arisen. In particular, some unfair social and some current situations that are difficult to use scientific interpretation have had a major impact on the ideological concepts of college students. The traditional education model It is difficult to answer the confusion of students. Many students have confusion in their consciousness. In addition, the difference in information identification also changes the students' minds. It is difficult to control a large amount of information resources on the Internet, creating opportunities for many lawless elements and weakening the morality of college students[4].

The problems caused by these diversified values have also brought a lot of troubles to the ideological and political education in China's colleges and universities. At present, the ideological and political education in China's colleges and universities urgently needs to solve the following problems. In the field of ideological and political education in colleges and universities, the core problem of college students' ideological and political education is to improve the quality of college students. In the comprehensive education of colleges and universities, ideological and political education has always been the top priority. Under the new situation, ideological and political education in colleges and universities must further study education. Efforts to improve the ideological and political quality and theoretical level of college students, the field of ideological and 
political education in universities must be further expanded, actively explore and think about the space of ideological and political education, constantly innovate the ideological and political education curriculum under the new situation, and increase the ability of college students to adapt to society.. College ideological and political education is mainly reflected in the thinking space, living space and learning space. Positive thinking and exploring the educational space can improve the ability of college students to identify the authenticity. In the expansion of education, college students are generally interested in the outside world. Therefore, the content of ideological and political education is also to be diversified and open to the world, and correctly guide the formation of college students' values[5]. The weights of the factors affecting ideological and political education are as follows.

Table 1: Weights of the factors affecting ideological and political education.

\begin{tabular}{|c|c|c|c|c|}
\hline Index & Society & University & Family & Environment \\
\hline Weight & 0.2655 & 0.4345 & 0.1202 & 0.1798 \\
\hline
\end{tabular}

In terms of the status of leading values in education, the values of college students are gradually diversified, and the same value evaluation criteria are gradually moving toward multiple developments. Many college students are difficult to correctly judge the value evaluation criteria, and the problems of utilitarian and individualized selection goals are different. It has brought a lot of troubles to the ideological and political education work. Many college students have a rejection of the original ideological and political education. Therefore, it is necessary to continuously innovate in the ideological and political education in colleges and universities. In terms of the ideological and moral aspects of college students, various ideas, theories and viewpoints of the society are full of them.

\section{Innovative Ways of Ideological and Political Education in Colleges and Universities under the Mode of Multi-Values}

In view of the problems brought about by the status quo of university students' diversified values, this paper proposes innovative education from the following aspects. In the ideological and political education of colleges and universities, the principle of students should be the main subject, which is close to the students' actual learning. For college students, the daily life is mainly learning, and the ideological and political education needs to guide students to formulate correct learning goals and stimulate students' learning durability. Sex and positivity. In the ideological and political education, it is also necessary to carry out guiding work for college students, help students to achieve their own goals, and put their energy into learning to guide students to develop good habits. After entering the university, students can say that they are completely separated from their parents' units. Ideological education needs to refer to the following key factors.

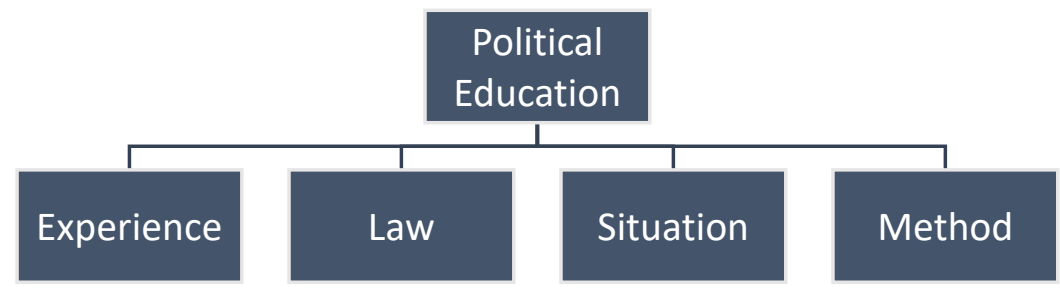

Figure 1: Ideological education needs to refer to the following key factors. 


\subsection{In the ideological and political education, we need to learn from the experience of western developed countries}

Western countries' ideological and political education has the characteristics of Western culture and has made great contributions to the education of political culture. For example, the United States attaches great importance to the study of penetrating education in education, and continues to use sociology, history and mechanics. Political education, researching and developing the law from the characteristics of college students' ideological development, and analyzing the values and education. Under the background of the diversified development of values, the ideological and political education work of Chinese college students also needs to study the development characteristics of values according to the characteristics of China. The introduction of ideals and beliefs and the education of ideology and morality in the curriculum. At present, ideological and political education in colleges and universities should emphasize individuality, integrate contemporary college students' ideological awareness, practical actions and emotional will into the ideological and political education, correctly guide the practical spirit and internal quality education of college students. The current ideals and beliefs and ideological and moral education cannot Relying on theoretical research or the mode of preaching, we must respect the internal and external laws in education, and study the inner needs of students through self-education and self-cultivation through in-class teaching and extracurricular teaching with life and society as carriers. The core of ideological and political education is the formation of socialist values, helping students to establish correct values. Therefore, educators need to return the knowledge base to action and carry forward Chinese traditional culture.

\subsection{In the innovation of ideological and political education, we need to follow the law of education}

Through the internalization and externalization of education, we will continue to deepen our educational philosophy and cultivate a society that meets the needs of social development. Specifically, in the ideological and political education, the educational content needs to be unified with the overall planning objectives. At present, the goal of ideological and political education in China is to train socialist successors. The ideological and educational education content system of colleges and universities needs to cultivate students' ideological education in all aspects. Moral education, political education, legal education, and psychological education. In terms of educational methods, it is necessary to combine local culture and national culture. Under the development of economic globalization, the cultures and values between countries have infiltrated and influenced each other. In ideological and political education, it is necessary to increase the study of different ideological and political education. And constantly absorbing the essence of foreign ideological and political education, China's ideological and political education not only needs to promote traditional culture, but also needs to absorb foreign culture, eliminate the dross, and realize the development and inheritance of local culture and tradition. In the aspect of education structure, it is necessary to unite with the hierarchy, perfectly combine practical activities and theoretical education, and truly realize ideological and moral education. In the face of diversified values, the form of education must gradually develop towards diversification, to achieve differentiated education, and to adopt appropriate educational methods for education in different periods.

\section{Conclusions}

In order to meet the challenges of global diversified values, universities need to continuously study the ideological and political education methods, analyze the relationship between historical 
development and changes in values, make full use of university information network technology, and try to answer the problems of college students in a theoretical and practical way. Education of ideals and beliefs, maintaining the vitality of ideological and political education. Create an incentive mechanism in ideological and political education, be good at using material rewards and spiritual rewards to stimulate the sense of responsibility of college students, and correctly guide the values of college students. Schools need to continuously build an integration mechanism, clarify the responsibilities of ideological and political education, and combine family education and social education to jointly promote student development.

\section{References}

[1] Renáta Bašková, Zuzana Struková. Innovation of education for the development of key competencies of university graduates[J]. Organization, Technology and Management in Construction: an International Journal,2017,9(1).

[2] Eddie Blass, Peter Hayward. Innovation in higher education; will there be a role for "the academe/university" in 2025[J]. European Journal of Futures Research,2014,2(1).

[3] Yanling Zhang. Analysis on the Path of the Innovation of the Cultural Quality-Oriented Education in University[J]. Creative Education,2015,06(03).

[4] Carol Poon Man Wai. Innovation and Social Impact in Higher Education: Some Lessons from Tohoku University and the Open University of Hong Kong[J]. Open Journal of Social Sciences, 2017,05(09).

[5] Luke Laan, Jenny Ostini. Enabling Innovative Postgraduate Research: Critical Foresight and Strategic Considerations for University Leaders[M].Springer Singapore:2018-06-19. 